\title{
FUNCTIONAL MAGNETIC RESONANCE IMAGING OF AUDITORY CORTEX IN PARTIAL DEAFNESS TREATMENT
}

\author{
Henryk Skarzynski ${ }^{1,2}$, Tomasz Wolak ${ }^{1,2}$, Agnieszka Pluta ${ }^{1,2}$, Monika Lewandowska ${ }^{1,2}$, \\ Mateusz Rusiniak ${ }^{1,2}$, Artur Lorens ${ }^{1,2}$, Lech Sliwa ${ }^{1,2}$, Piotr H. Skarzynski ${ }^{1,3}$, Lukasz Olszewski ${ }^{1,2}$ \\ ${ }^{1}$ Institute of Physiology and Pathology of Hearing, ul. Zgrupowania AK “Kampinos" 1, 01-943 Warszawa, Poland \\ ${ }^{2}$ World Hearing Center, ul. Mokra 17, Kajetany 05-830 Nadarzyn, Poland \\ ${ }^{3}$ Institute of Sensory Organs, ul. Mokra 1, Kajetany 05-830 Nadarzyn, Poland
}

Corresponding author: Tomasz Wolak, e-mail: t.wolak@ifps.org.pl, Agnieszka Pluta, e-mail: a.pluta@ifps.org.pl

\begin{abstract}
Background: Recently, there has been a surge of interest in neuroimaging techniques that might help to objectively evaluate the residual hearing abilities of patients with hearing abilities of patients considered for partial deafness treatment (PDT). Such an evaluation might allow a wider range of PD candidates to benefit from cochlear implantation (CI). Although existing studies suggest that functional magnetic resonance (fMRI) may help predict the benefits of CI for hearing-impaired patients, little is known about the activity of the primary auditory cortex in patients with partial deafness. This study is the first to apply fMRI to examine BOLD signal changes in the auditory cortex induced by chirp stimulation in patients with partial deafness.
\end{abstract}

Material and Method: Ten patients considered for partial deafness treatment with electro-acoustic stimulation (PDT-EAS) and 10 patients considered for electrical complement treatment (PDT-EC) according to Skarżyński’s categorization of partial deafness treatment (PDT) participated in the study. fMRI measurements were performed in a 3T Siemens Magnetom Trio scanner at the Bioimaging Research Center (BRC) of the Institute of Physiology and Pathology of Hearing in Kajetany, Poland.

During the fMRI study, subjects were presented with a chirp of two different bandwidths: $50-950 \mathrm{~Hz}$ (middle frequency $500 \mathrm{~Hz}$ ) and $3000-5000 \mathrm{~Hz}$ (middle frequency $4000 \mathrm{~Hz}$ ) at $90 \mathrm{~dB}(\mathrm{C})$ via MRI-compatible earphones. A sparse paradigm was used and the data was analyzed using the SPM8 package (Statistical Parametric Mapping, http://www.fil.ion.ucl.ac.uk/spm/). Standard preprocessing was followed by a second-level analysis for contrast of low and high frequencies.

Results: As expected, bilateral activation in the auditory cortex was observed in response to stimulation by $500 \mathrm{~Hz}$ chirps in PDT-EAS and PDT-EC candidates. Activation in response to $4000 \mathrm{~Hz}$ chirps were found only in the PDT-EAS group but less strongly than for $500 \mathrm{~Hz}$ chirps.

Conclusions: fMRI can be used as an objective way of assessing residual hearing in the auditory cortex of patients with partial deafness.

Key words: fMRI • partial deafness treatment • PDT-EAS

\section{RESONANCIA MAGNÉTICA FUNCIONAL DE LA CORTEZA AUDITIVA EN EL TRATAMIENTO DE LA SORDERA PARCIAL}

\section{Resumen}

Antecedentes: Recientemente, se mostró gran interés en las técnicas de neuro-imagen que pueden ayudar a evaluar objetivamente las capacidades auditivas residuales de los pacientes con capacidades auditivas y de los pacientes considerados para el tratamiento de la sordera parcial (PDT). Dicha evaluación podría permitir a un grupo más amplio de candidatos con sordera parcial a beneficiarse de un implante coclear (IC). Aunque los estudios existentes sugieren que la resonancia magnética funcional (IRMf) puede ayudar a predecir los beneficios de la IC para los pacientes con deficiencias auditivas, se sabe poco sobre la actividad de la corteza auditiva primaria en pacientes con sordera parcial. Este estudio es el primero en aplicar la IRMf para examinar los cambios de la señal BOLD en la corteza auditiva inducida por la estimulación chirrido en los pacientes con sordera parcial.

Material y método: En el estudio participaron diez pacientes considerados para el tratamiento de la sordera parcial con estimulación electro-acústica (PDT-EAS) y 10 pacientes considerados para el tratamiento de complemento eléctrico (PDT-CE), de acuerdo con las categorías de Skarzynski sobre el tratamiento de la sordera parcial (PDT) que participaron en el estudio. Las mediciones de resonancia magnética funcional se realizaron en un escáner 3T Siemens Magnetom Trio en el Bioimaging Research Center (BRC), del Instituto de Fisiología y Patología de la Audición en Kajetany, Polonia. Durante el estudio de resonancia magnética funcional, los pacientes se estudiaron con un chirrido de dos anchos de banda diferentes: $50-950 \mathrm{~Hz}$ (frecuencia media de $500 \mathrm{~Hz}$ ) y $3000-5000 \mathrm{~Hz}$ (frecuencia media de $4000 \mathrm{~Hz}$ ) a $90 \mathrm{~dB}(\mathrm{C})$ a través de resonancia magnética compatibles 
con audífonos. Se utilizó un paradigma escaso y los datos fueron analizados mediante el paquete SPM8 (Statistical Parametric Mapping, http://www.fil.ion.ucl.ac.uk/spm/). El preprocesamiento fue seguido por un análisis de segundo nivel para el contraste de las frecuencias bajas y altas.

Resultados: Como era de esperar, la activación bilateral en la corteza auditiva se observó en respuesta a la estimulación con chirridos de $500 \mathrm{~Hz}$ en candidatos para PDT-EAS y PDT-CE. La activación en respuesta a los chirridos de $4000 \mathrm{~Hz}$ sólo se notó en el grupo PDT-EAS, pero con menos intensidad que en chirridos de $500 \mathrm{~Hz}$.

Conclusiones: La IRMf se puede utilizar como una forma objetiva de evaluar la audición residual en la corteza auditiva de los pacientes con la sordera parcial.

Palabras clave: resonancia magnética funcional • el tratamiento de la sordera parcial • PDT-EAS

\section{IMAGERIE PAR RESONANCE MAGNETIQUE DU CORTEX AUDITIF DANS LE TRAITEMENT DE SURDITE PARTIELLE}

\section{Résumé}

Contexte: Récemment, il ya eu un regain d'intérêt pour les techniques de imagerie neurale qui pourraient aider à évaluer de manière objective les capacités auditives résiduelles de patients susceptible de bénéficier du traitement de la surdité partielle. Une telle évaluation pourra permettre à un plus grand nombre de candidats atteint de surdité partielle de bénéficier de l'implantation cochléaire. Bien que les études existantes suggèrent que la résonance magnétique fonctionnelle (IRMf) puisse aider à prédire les bénéfices d'une implantation cochléaire pour les patients malentendants, on connaît peu de chose sur l'activité du cortex auditif primaire chez les patients atteints de surdité partielle. Cette étude est la première à appliquer la résonance magnétique fonctionnelle pour examiner le changement de signal dépendant de niveau doxygénation sanguin dans le cortex auditif induit par une stimulation à base de chirps chez les patients atteints de surdité partielle.

Matériel et méthode: Dix patients susceptibles de bénéficier d’un traitement de la surdité partielle grâce à la stimulation électro-acoustique et 10 patients susceptibles de bénéficier d'un traitement électrique complémentaire, selon la catégorisation de Skarzynski de traitement de la surdité partielle ont participés à létude. Les mesures par IRMf ont été réalisées dans un scanner Siemens 3T Trio Magnetom au centre de recherche de bio-imagerie de l'Institut de physiologie et de pathologie auditive de Kajetany en Pologne. Durant l'IRMf, les sujets ont été soumis à un chirp de deux bandes passantes différentes: 50-950 Hz (fréquence moyenne de $500 \mathrm{~Hz}$ ) et 3000-5000 Hz (fréquence moyenne $4000 \mathrm{~Hz}$ ) ce à $90 \mathrm{~dB}(\mathrm{C}$ ) par l'intermédiaire d'écouteurs compatibles avec l'IRM. Un rare paradigme a été utilisé et les données ont été analysées en utilisant le paquet SPM8 (La cartographie statistique paramétrique, $h t t p: / / w w w . f i l . i o n . u c l . a c . u k / s p m /)$. Un prétraitement standard a été suivi d'une analyse de second niveau pour un contraste des basses et hautes fréquences.

Résultats: Comme prévu, l'activation bilatérale dans le cortex auditif a été observée en réponse à une stimulation par des chirps de $500 \mathrm{~Hz}$ chez les candidats pour le traitement de surdité partielle avec la stimulation électro-acoustique et par le traitement électrique complémentaire. Une activation en réponse à des chirps de $4000 \mathrm{~Hz}$ a été observé uniquement dans le groupe de candidats au traitement de la surdité partielle par stimulation électro-acoustique, mais moins fortement que pour les chirps de $500 \mathrm{~Hz}$.

Conclusions: L'IRMf peut être utilisée comme un moyen objectif d'évaluation de l'audition résiduelle dans le cortex auditif des patients atteints de surdité partielle.

Mots clés: Imagerie par résonance magnétique fonctionnelle IRMf • Traitement de la surdité partielle • Traitement de la surdité partielle par la stimulation électro-acoustique

\section{ФУНКЦИОНАЛЬНАЯ МАГНИТНО-РЕЗОНАНСНАЯ ТОМОГРАФИЯ СЛУХОВОЙ ЗОНЫ КОРЫ ГОЛОВНОГО МОЗГА ПРИ ЛЕЧЕНИИ ЧАСТИЧНОЙ глУХОТЫ}

\section{Краткий обзор}

История вопроса: В последнее время наблюдается всплеск интереса к технологиям нейровизуализации, способствующим объективной оценке остаточных слуховых возможностей у пациентов со слуховыми возможностями или пациентов, направленных на лечение частичной глухоты (PDT). Такая оценка может способствовать получению положительного результата от кохлеарной имплантации (CI) для более широкого спектра пациентов с PD. Несмотря на то, что проведенные исследования подтверждают эффективность функционального магнитного 
резонанса (фЯМР) в прогнозировании положительного эффекта от СI у пациентов с нарушениями остроты слуха, сведения об активности первичной слуховой зоны коры головного мозга у пациентов с частичной глухотой крайне скудны. В данном исследовании впервые предпринята попытка применения фЯМР для исследования изменений сигнала в системе BOLD в слуховой зоне коры при стимуляции сигналом с частотной модуляцией у пациентов с частичной глухотой.

Материалы и методы: В исследовании участвовало десять пациентов, направленных на лечение частичной глухоты с помощью электроакустической стимуляции (PDT-EAS) и 10 пациентов, направленных на дополняющее лечение электрической стимуляцией (PDT-EC), на основании классификации видов лечения частичной глухоты (PDT) Скаржинского. Процедуры фЯМР проводили с помощью сканирующей системы 3T Siemens Magnetom Trio в Исследовательском центре биовизуализации (Bioimaging Research Center - BRC) Института физиологии и патологии слуха в г. Кайетаны, Польша. В ходе исследований фЯМР пациенты подлежали воздействию сигнала с частотной модуляцией в различных частотных диапазонах: 50-950 Гц (средняя частота 500 Гц) и 3000-5000 Гц (средняя частота 4000 Гц) при 90 дБ(С) при посредстве ЯМР-совместимых наушников. Была применена модель разреженной активации, данные анализировали с помощью программного пакета SPM8 (Statistical Parametric Mapping, http://www.fil.ion.ucl.ac.uk/spm/). После стандартной предварительной обработки применяли анализ второго уровня для сравнения результатов при высоких и низких частотах.

Результаты: Как и предполагалось, билатеральная активация слуховой зоны коры была отмечена при стимуляции сигналом с частотной модуляцией при 500 Гц у пациентов с PDT-EAS и PDT-EC. Ответная активация при воздействии сигнала частотой 4000 Гц наблюдалась лишь в группе с PDT-EAS, но с меньшей степенью выраженности, чем при 500 Гц.

Заключение: метод фЯМР может быть использован в качестве объективного средства оценки способности к остаточной слышимости слуховой зоны коры у пациентов с частичной глухотой.

Ключевые слова: фЯМР • лечение частичной глухоты • PDT-EAS

\section{Background}

Hearing loss is a serious problem in modern society as it affects social behavior, renders routine communication difficult, and drastically reduces quality of life. Recent advances in technology and signal processing have resulted in various devices designed to improve or restore hearing [1-4]. Among these, electrical stimulation by a cochlear implant (CI) in patients with profound hearing loss has provided a huge benefit in restoring useful hearing.

However, there is a large group of patients with a significant level of residual low-frequency hearing who remain beyond the scope of effective treatment by hearing aids alone. These patients are significantly impaired, as they cannot communicate effectively in everyday situations and have major problems in understanding speech in noise. This condition has been termed "partial deafness" (PD). In the past, cochlear implantation in PD patients was contraindicated due to the fear that the procedure may damage the residual function of the cochlea and result in complete deafness. However, development of the round window approach proposed by Skarzynski [5] has proven to be an effective way of preserving hearing compared to conventional cochleostomy.

In 2002 the first successful cochlear implantation in a PD patient was performed. Post-implantation evaluation demonstrated significant improvement in speech discrimination and communication skills. Further research has resulted in a four-way categorization scheme of partial deafness treatment (called a Concept of Partial Deafness Treatment in [6] that distinguishes the following groups of patients.
1. The PDT-acoustic stimulation (AS) group in whom hearing is amplified with hearing aids.

2. The PDT-electrical complement (EC) group has relatively good hearing at low frequencies (up to $1000-1500 \mathrm{~Hz}$ ) and so no acoustic amplification is required for these frequencies; however, the high-frequency regions of the cochlea need electrical stimulation from a cochlear implant electrode array, such as the MED-EL M, FlexEAS Standard, or FlexSOFT (Med-EL, Innsbruck, Austria) with a $20 \mathrm{~mm}$ insertion (or recently $28 \mathrm{~mm}$ ), or the Cochlear CI422 (formerly SRA) [7,8] (Cochlear Ltd, Sydney, Australia).

3. The PDT-electro-acoustic stimulation (EAS) group are patients in whom "low frequencies are preserved during shallow cochlear implantation, and are amplified with an in-the-ear hearing aid"[9]. This group of patients has mild-to-severe hearing loss at low frequencies and profound hearing loss at high frequencies.

4. The PDT-electrical stimulation (ES) group has little residual hearing and little chance of benefitting from acoustic amplification. Therapeutic intervention involves partial or deep CI electrode insertion and aims at hearing preservation $[7,10]$.

Considerable improvement in cochlear implant technology has resulted in a widening of selection criteria and it has encouraged clinicians to rethink the factors that impinge on the decision of whether to prescribe a CI. Although there is general agreement that the duration of deafness should be considered, other factors predicting CI outcomes need to be elucidated [11].

Recent studies have suggested that a crucial factor which may account for the large variability obtained in speech 

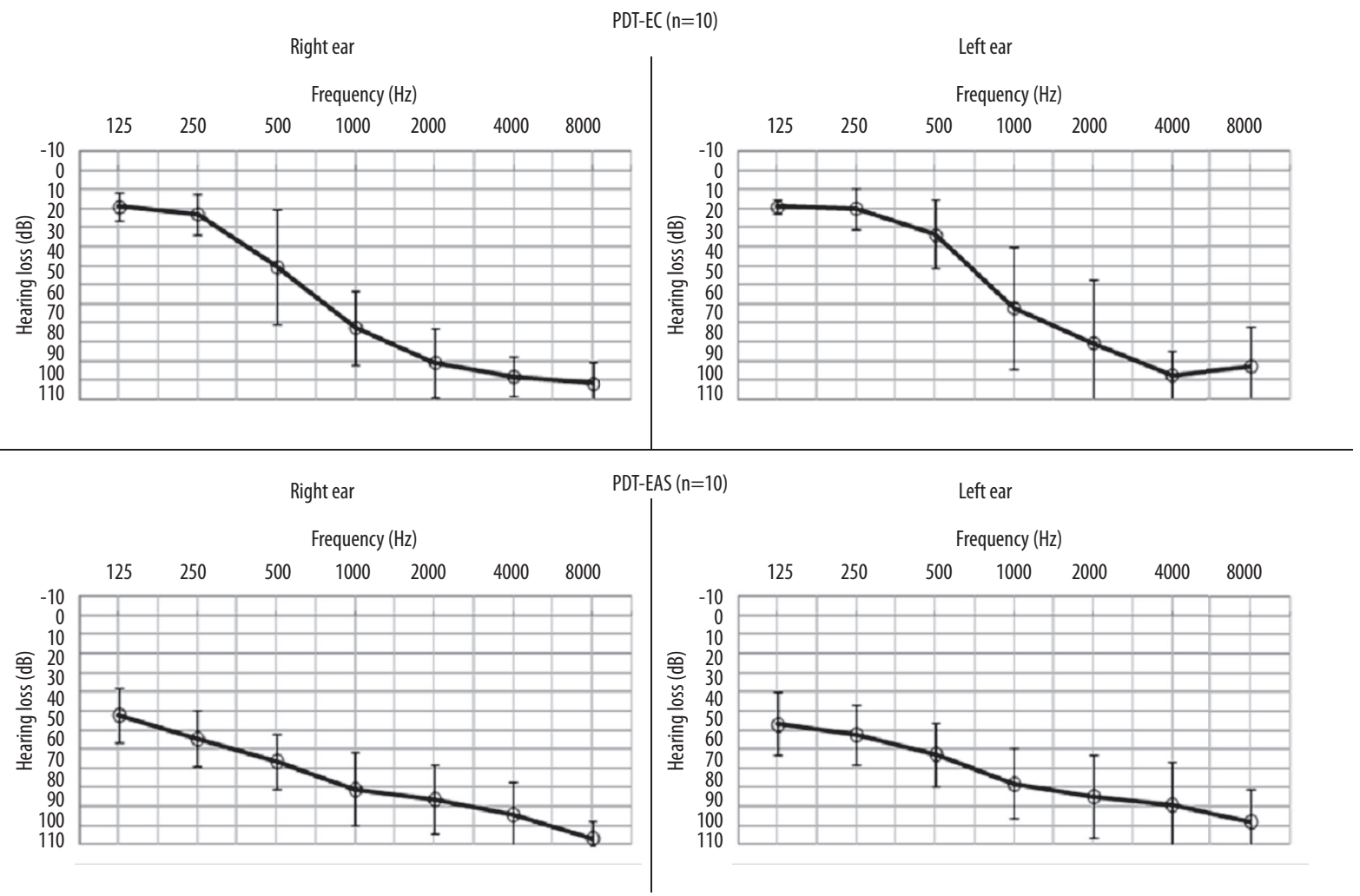

Figure 1. Mean audiograms in the PDT-EC and PDT-EAS groups.

tests after implantation is one related to metabolic activity in cerebral auditory regions, and this activity can be measured pre-operatively $[12,13]$. Therefore new methods could provide objective and detailed information about higher auditory cortical processing. Recently, there has been a surge of interest in neuroimaging techniques - in particular fMRI - that might assist in examining the residual function of the central auditory pathway [14].

Many attempts have been made to evaluate auditory cortex activation in response to auditory stimulation with healthy people, but only a few research groups have conducted fMRI studies to investigate the primary auditory cortex in deaf patients $[15,16]$. Patel et. al. [15] indicated that in hearing-impaired infants and children the amount of auditory cortex activity as revealed by fMRI relates to an improvement in post-implantation assessment. Lazard et al. [16] used an fMRI technique on patients with postlingual deafness to complement the available behavioral data and tried to predict the outcome of cochlear implantation. The study suggested that patients who become effective implant users recruit different brain networks while processing speech compared to patients who do not benefit from the surgery.

The existing studies suggest that fMRI may assist in predicting the communication benefits from CIs in hearingimpaired patients. Nevertheless, little is known about the auditory cortex responses of patients with partial deafness [17]. This study aims to investigate brain activity in response to chirps in patients with different types of partial deafness. To our knowledge it is the first study which applies fMRI techniques to examine auditory cortex functions in PDT-EAS and PDT-EC candidates according to the classification proposed by Skarzynski et al., 2010 [6].

\section{Material and Methods}

\section{Subjects}

Twenty patients with partial deafness, aged from 12 to 60 years (mean age $=42$ years and 7 months, standard deviation $=14$ years 4 months) were included. Prior to the fMRI experiment, patients underwent pure tone audiometry using standard frequencies of 125, 250, 500, 1000, 2000, 4000 , and $8000 \mathrm{~Hz}$. On the basis of the audiological assessment patients were considered for electrical complement treatment (PDT-EC) (mean age $=32$ years and 10 months) or electro-acoustic stimulation treatment (PDTEAS) (mean age $=32$ years and 10 months) or PDT-EAS (mean age $=52$ years and 6 months) with a standard deviation of 5 years. The mean audiograms for each PDT group are presented in Figure 1.

\section{fMRI procedure}

\section{MRI measurements}

The study was performed in a 3T Siemens Magnetom Trio scanner at the Bioimaging Research Center of the Institute of Physiology and Pathology of Hearing in Kajetany, Poland. T1-weighted structural images were acquired with an isotropic voxel size of $0.9 \times 0.9 \times 0.9 \mathrm{~mm}$. Functional data was obtained with a gradient-echo EPI sequence. 

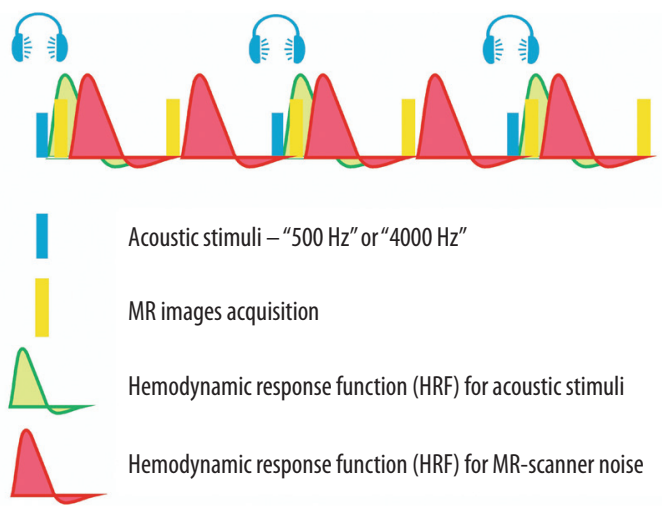

Figure 2. The sparse stimulus paradigm.

Two functional runs were acquired with TR of $18,000 \mathrm{~ms}$ and TE of $30 \mathrm{~ms}$. A single volume was acquired as fast as possible during each TR period (about $3000 \mathrm{~ms}$ starting from the beginning of the TR period) so that throughout the rest of the TR period there was no acoustic noise generated by gradients. Each functional series contained 50 volumes (each volume consisted of 48 slices, and the signal was acquired with a physical matrix of $64 \times 64$ ). Voxel size of the functional images was $3 \times 3 \times 3 \mathrm{~mm}$. Morphological images of the whole brain were also obtained using standard T2-weighted sequences to exclude neurological pathology.

\section{Scanning procedure}

In this study an event-related sparse paradigm was used. In this design the stimulus is short, usually under 1 second. Neuronal activation lasting as short as $40 \mathrm{~ms}$ still produces a measurable change in the BOLD fMRI response. Stimuli of very short duration can be used in an event-related design, allowing more real-world testing. However, the statistical power of event-related designs is inherently low, because the signal change in the BOLD fMRI signal following a single stimulus presentation is small. Importantly, when two or more stimuli are presented in rapid succession, the BOLD fMRI response increases roughly linearly.
During fMRI evaluation subjects were presented with two different chirps at $90 \mathrm{~dB}(\mathrm{C})$ via MRI-compatible earphones: one with a middle frequency of $500 \mathrm{~Hz}$ $(50-950 \mathrm{~Hz})$ and a second with a middle frequency of $4000 \mathrm{~Hz}(3000-5000 \mathrm{~Hz})$; for simplicity, these are referred to as chirps of $500 \mathrm{~Hz}$ and $4000 \mathrm{~Hz}$. A burst scanning mode of image acquisition was used, meaning that all the slices in one volume were acquired as fast as possible and the rest of the TR period was a gap. The acquisition of the whole brain image took $3000 \mathrm{~ms}$, during which the MRI scanner generated noise of $99 \mathrm{~dB}$ SPL (attenuated to ca. $80 \mathrm{~dB}$ SPL by headphones). The study was designed to give $15 \mathrm{~s}$ intervals between consecutive image acquisitions excluding the acquisition time (without noise). For 5 seconds before each image acquisition, 3 repetitions of $1 \mathrm{~s}$ chirps were presented. Due to delay in the hemodynamic response (the hemodynamic response reaches its maximum value about 5-6 seconds after stimulus presentation), we expected the maximum response to a given stimulus to occur at the moment of image acquisition. The next period, in which the image acquisition was not preceded by a chirp, was later used as a reference to the stimulus acquisition period. The study design is shown in Figure 2.

\section{Data analysis}

An fMRI data acquisition usually involves collection of many thousands of magnetic susceptibility images, and the result is typically displayed as a color overlay map or statistical parametric map in which a bright color indicates areas of activation. The fMRI experiment can simply be considered as a subtraction in which the images acquired during two or more conditions are subtracted to identify differences in regional signal intensity associated with differences in experimental conditions. The fMRI data were analyzed using the SPM8 package (Statistical Parametric Mapping, http://www. fil.ion.ucl.ac.uk/spm/). Data preprocessing comprised the following steps: 1) motion correction to eliminate motion artifacts; 2) EPI images correction of geometric distortion caused by tissue inhomogeneities; 3 ) normalization of the brain images; and 4) smoothing. Preprocessing was used to remove various kinds of artefacts in the data in order to maximize sensitivity and improve the validity of later statistical analysis.

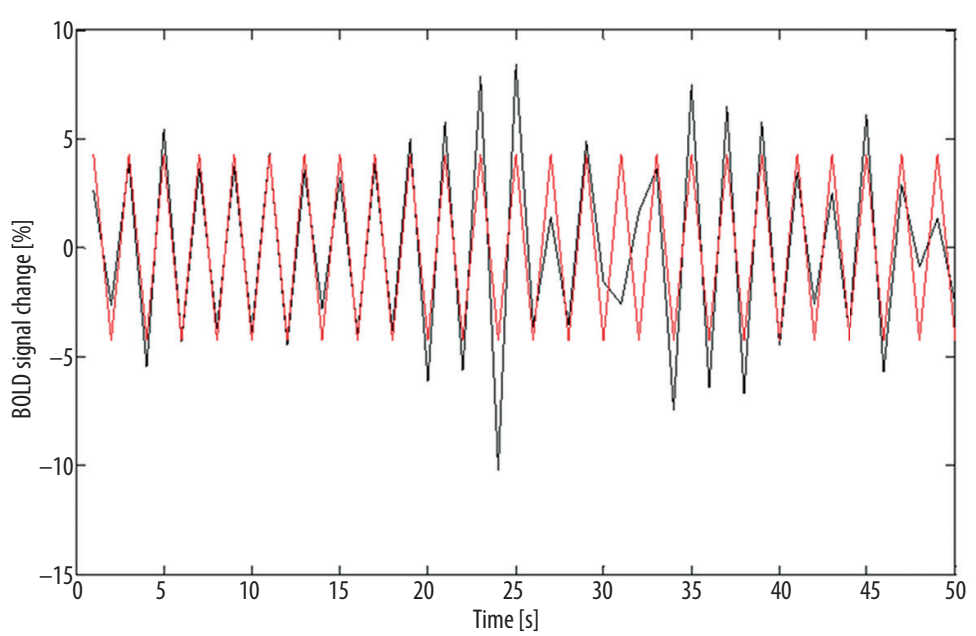

Figure 3. Example of mean regional response (black) with a hemodynamic model fitted to the data (red). 


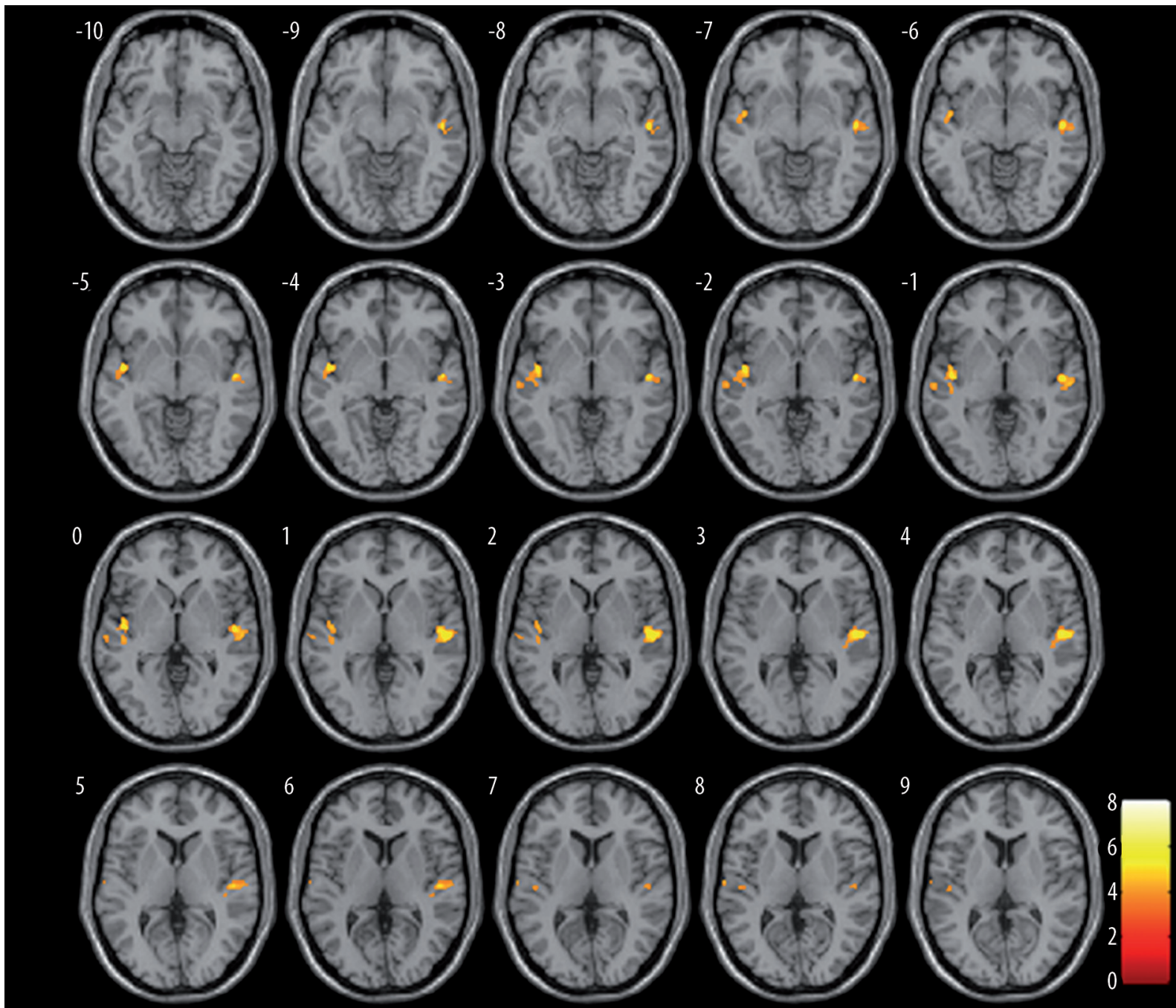

Figure 4. Comparison of brain activation induced by low $(500 \mathrm{~Hz})$ and high $(4000 \mathrm{~Hz})$ frequency chirps in the PDT-EAS group (paired t-test, contrast $500 \mathrm{~Hz}$ vs. $4000 \mathrm{~Hz}, p<0.001$ uncorrected).

The fMRI analysis assumes that the same voxel always represents the same location in the brain. For good fMRI resolution (low motion artifacts), head motion needs to be kept below $1 \mathrm{~mm}$. Head motion of 1-2 mm might be correctable, depending on the sort of motion, but anything above $3 \mathrm{~mm}$ is rejected. If movements are correlated with the stimuli presentation, false activity can be generated; if there is no correlation, changes in voxel intensity will add noise to the signal and the poorer signal-to-noise ratio will decrease the statistical power.

The goal of normalization of brain images is to transform motion-corrected volumes into a roughly standard space in order to allow automatic registration of anatomical regions. In this study normalization was performed for analysis by groups and for comparison of results between patients. Image smoothing involved low pass filtering which convolved the voxels in the EPI images with a kernel according to an applied filter. Smoothing improved image quality by increasing the signal-to-noise ratio and decreasing anatomical differences between subjects.

General linear modeling (GLM) was used to fit a model to the data (Figure 3). The model was derived from the timing of the stimulus. A good fit between the model and the data means that the brain activations were caused by the stimuli. GLM fits the model to a single voxel's timecourse. For all voxels $\beta$ parameters were estimated, $\beta$ being the value that the model had to be multiplied by to fit the signal changes in the real data.

Figure 3 shows an example of the BOLD signal change with the fitted hemodynamic model determined on the basis of GLM analysis. Percent of signal change was calculated. It was found that the percent of BOLD signal change was proportional to the amount of neural activation. For each patient, values of the BOLD percent signal change were determined separately for low $(500 \mathrm{~Hz})$ and high $(4000 \mathrm{~Hz})$ frequencies.

The second-level analysis (paired $t$-test) was conducted for the low and high frequencies contrast.

\section{Results}

The fMRI analysis revealed that PDT-EAS and PDT-EC candidates demonstrated significant bilateral activation in the auditory cortex in response to stimulation by a $500 \mathrm{~Hz}$ chirp vs. a $4000 \mathrm{~Hz}$ chirp ( $p<0.001$, uncorrected). Maximum 


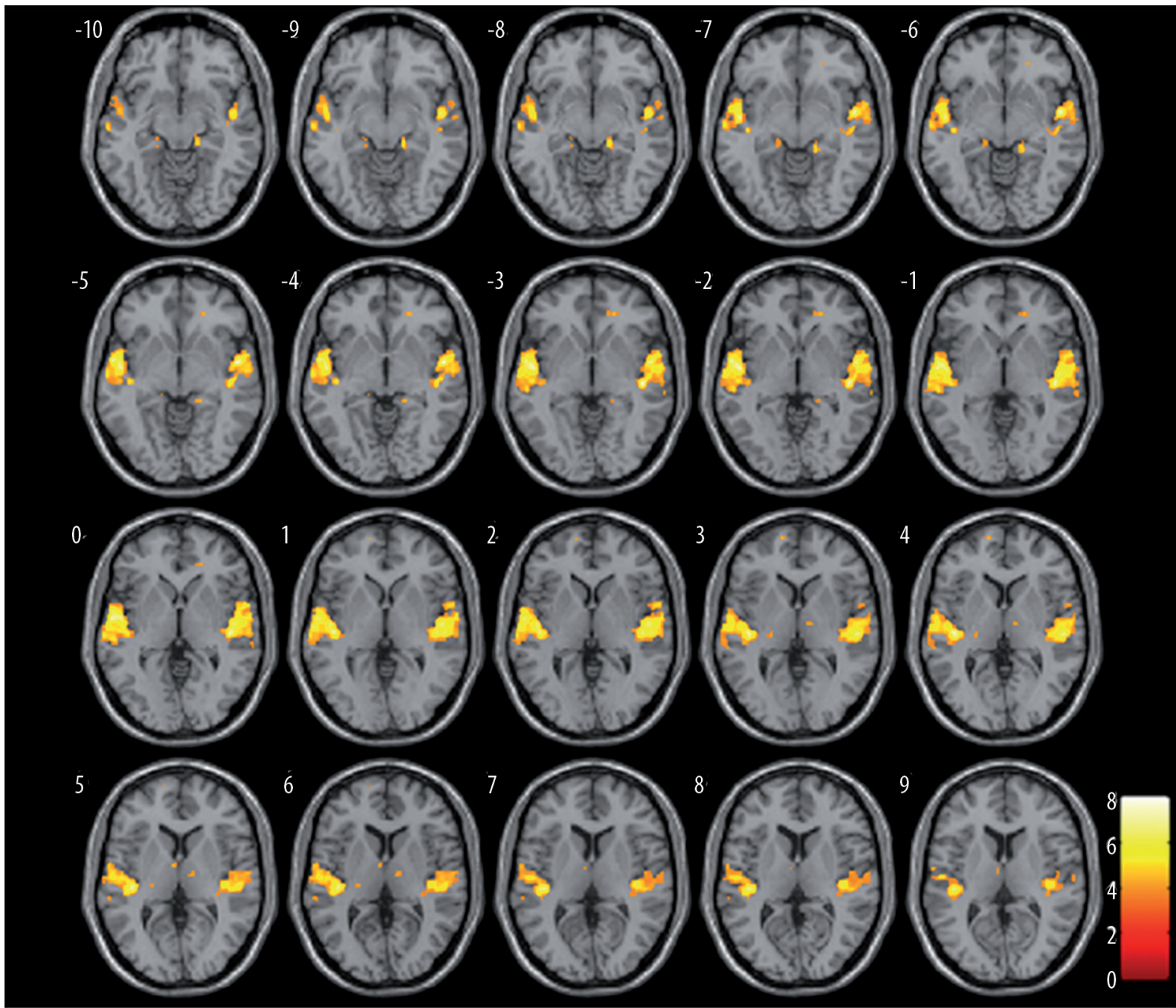

Figure 5. Comparison of brain activation induced by low $(500 \mathrm{~Hz})$ and high $(4000 \mathrm{~Hz})$ frequency chirps in the PDT-EC group (paired t-test, contrast $500 \mathrm{~Hz}$ vs. $4000 \mathrm{~Hz}, p<0.001$, uncorrected).

activation was observed bilaterally in the superior temporal gyrus. Paired-sample $t$-tests were used to compare mean activations. The results are presented in Figure 4 for the PDTEAS group and in Figure 5 for the PDT-EC group. The colours highlight regions where differences between activations in response to low $(500 \mathrm{~Hz})$ vs. high $(4000 \mathrm{~Hz})$ frequencies were significant. It is noteworthy that the PDT-EAS group shows smaller activation areas than the PDT-EC group.

\section{Discussion}

Our study is the first to apply fMRI to investigate soundinduced BOLD signal changes in patients with partial deafness (both PDT-EAS and PDT-EC candidates). The resulting data are in line with the existing scarce neuroimaging literature showing that fMRI may be a useful method for detecting central auditory activation in patients with different severities of hearing loss $[15,18]$.

Candidates for PDT-EAS and PDT-EC intervention showed BOLD responses within the bilateral superior temporal gyri in response to $500 \mathrm{~Hz} v s .4000 \mathrm{~Hz}$ chirps. The largest contrast was obtained with the PDT-EC group (see Figures 4 and 5). These data are congruent with the hearing loss profiles of both PDT groups, i.e. more severe hearing deficits in the high frequency range compared to the low frequency one.

The cortical activity of PDT-EAS and PDT-EC candidates clearly indicates that they have residual cortical capacity in response to the detected sounds, with different activation patterns in each group. Our study indicates that our fMRI protocol may be a useful tool for investigating the brain mechanisms of partial deafness

Our study involved only two groups of patients considered for partial deafness treatment : PDT-EAS and PDTEC. Further examination is required to assess central auditory processing in the remaining PDT groups. It should be emphasized that the PDT classification scheme is relatively new, and a larger cohort of patients will be recruited in the near future. It will be interesting to see whether age and the duration of deafness affect activity in the auditory cortex. Future analysis might also look at correlating the post-implantation outcomes of language tests with the preimplantation BOLD responses. By providing detailed characteristics of cortical activity within PDT patients such a study might be able to provide a prognosis of CI outcomes. 


\section{Conclusions}

In conclusion, our preliminary results have shown that fMRI can be successfully applied to examine BOLD signal changes in auditory cortex induced by chirp stimulation in patients with partial deafness. Importantly, fMRI can be used as an objective method of assessing residual function of the auditory cortex in PDT patients.

\section{Acknowledgments}

We would like to thank Katarzyna Ciesla for linguistic corrections and valuable comments on this paper.

\section{References:}

1. Djourno A, Eyries C: Prothese Auditive par Excitation Electrique a Distance du Nerf Sensoriel a Laide dun Bobinage Inclus a Demeure. Presse Med, 1957; 65: 1417-17

2. House WF: Cochlear Implants. Ann Oto Rhinol Laryn, 1976; 85: 3-93

3. House W: Cochlear Implants - Past, Present and Future. Cochlear Implants: New Perspectives, 1993; 48: 1-3

4. Mills M: Hearing Aids and the History of Electronics Miniaturization. Ieee Ann Hist Comput, 2011; 33: 24-44

5. Skarzynski $\mathrm{H}$, Lorens A, Piotrowska A: A new method of partial deafness treatment. Med Sci Monit, 2003; 9(4): CS20-24

6. Skarzynski H, Lorens A, Piotrowska A, Anderson I: Partial deafness cochlear implantation provides benefit to a new population of individuals with hearing loss. Acta Otolaryngol, 2006; 126: 934-40

7. Skarzynski H, Lorens A, Piotrowska A, Podskarbi-Fayette R: Results of Partial Deafness Cochlear Implantation Using Various Electrode Designs. Audiol Neuro-otol, 2009; 14: 39-45

8. Skarzynski H, Lorens A, Matusiak M et al: Partial Deafness Treatment with the Nucleus Straight Research Array Cochlear Implant. Audiol Neurotol, 2012; 17: 82-91

9. Skarzynski H, Lorens A, Piotrowska A, Skarzynski PH: Hearing preservation in partial deafness treatment. Med Sci Monit, 2010; 16(11): CR555-62

10. Skarzynski H, Lorens A, Zgoda $M$ et al: Atraumatic round window deep insertion of cochlear electrodes. Acta Oto-Laryngol, 2011; 131: 740-49
11. Lee H-J, Kang E, Oh S-H et al: Preoperative differences of cerebral metabolism relate to the outcome of cochlear implants in congenitally deaf children. Hear Res, 2005; 203: 2-9

12. Lee DS, Lee JS, Oh SH et al: Deafness: Cross-modal plasticity and cochlear implants. Nature, 2001; 409: 149-50

13. Lee H-J, Giraud A-L, Kang E et al: Cortical Activity at Rest Predicts Cochlear Implantation Outcome. Cereb Cortex, 2007; 17: 909-17

14. Schmidt AM, Weber BP, Vahid M et al: Functional MR Imaging of the Auditory Cortex with Electrical Stimulation of the Promontory in 35 Deaf Patients Before Cochlea Implantation. AJNR Am J Neuroradiol, 2003; 24: 201-7

15. Patel AM, Cahill LD, Ret J et al: Functional Magnetic Resonance Imaging of Hearing-Impaired Children Under Sedation Before Cochlear Implantation. Arch Otolaryngol Head Neck Surg, 2007; 133: 677-83

16. Lazard DS, Lee HJ, Gaebler M et al: Phonological processing in post-lingual deafness and cochlear implant outcome. NeuroImage, 2010; 49: 3443-51

17. Lambertz N, Gizewski ER, de Greiff A, Forsting M: Crossmodal plasticity in deaf subjects dependent on the extent of hearing loss. Brain Res Cogn Brain Res, 2005; 25: 884-90

18. Holland SK, Choo DI, Ret JK et al: fMRI of severe to profoundly hearing-impaired infants and toddlers under sedation. International Congress Series, 2004; 1273: 383-86 